\title{
STOSOWANIE MEDIÓW CYFROWYCH W EDUKACJI WYŻSZEJ \\ - KONFRONTACJA OPINII NAUCZYCIELI AKADEMICKICH I STUDENTÓW
}

\begin{abstract}
AвSTRACt. Klimas Patrycja, Stosowanie mediów cyfrowych w edukacji wyższej - konfrontacja opinii nauczycieli akademickich $i$ studentów [Application of Digital Media in Higher Education - a Juxtaposition of Opinions of Both Academic Teachers and Students]. Studia Edukacyjne nr 49, 2018, Poznań 2018, pp. 269-280. Adam Mickiewicz University Press. ISSN 1233-6688. DOI: 10.14746/se.2018.49.16
\end{abstract}

Recommendations made by policy makers, increasing competitive pressure and growing popularity of digital media among participants of teaching processes contribute to their increasingly extensive use at Polish universities. The fact that the teaching processes has entered the new, digital dimension reveals the need for information concerning the relevance of use of electronic media, especially from the perspective of achieving learning outcomes. Given the above, the purpose of this paper is to present results of research on opinions of both students and academics on the need and significance of the application of digital media in the learning processes.

For the purposes of the article, a quantitative research was conducted among 86 students and 66 teachers from University of Economics in Katowice. The data was collected in April 2015 using an online surveying technique and analyzed using statistical description.

In the light of our results, the application of electronic media seems to not only be imposed by macroand micro-environmental conditions, but also to be expected by the main participants of educational processes taking place at university level. The results show that both groups of respondents consider the use of digital media at least as advisable for the achievement of learning outcomes $(71.8 \%$ of responses covered labels: advisable, recommended or required). However, the level of necessity is slightly higher when digital tools are used by students (80.7\%) than by teachers (70.3\%). In general, multimedia presentations have been identified as the most required form of digital media application in teaching at the university.

Key words: digital media, electronic media, higher education, education performance, modern teaching 


\section{Wprowadzenie}

Nowoczesne technologie oparte na wykorzystaniu szerokiego spectrum mediów cyfrowych stanowią jeden z wyróżników współczesnego świata, w tym także w coraz większym stopniu świata nauki i edukacji. Stałe upowszechnianie oraz rosnąca popularyzacja stosowania mediów elektronicznych $\mathrm{w}$ nauczaniu skłania do postawienia pytania, jak ten trend oceniają główni uczestnicy procesów dydaktycznych. Pytanie to jest tym bardziej zasadne, iż wśród kadry dydaktycznej słychać głosy o wyższości nie-cyfrowego przekazu wiedzy, a jednocześnie wśród studentów zaczynają pojawiać się oznaki znużenia kursami przez platformy elektroniczne, czy różnego typu prezentacjami. Stąd też, celem niniejszego artykułu jest prezentacja wyników badań dotyczących rozpoznania opinii na temat zasadności stosowania różnego typu mediów cyfrowych w procesach dydaktycznych na poziomie szkolnictwa wyższego. Badania stanowiące podstawę rozważań zaprezentowanych w opracowaniu przeprowadzono wśród studentów oraz nauczycieli akademickich Uniwersytetu Ekonomicznego w Katowicach. W świetle ich rezultatów można stwierdzić, iż wykorzystanie zróżnicowanych mediów cyfrowych - zarówno w opinii studentów, jak i prowadzących zajęcia dydaktyczne - jest zalecane z punktu widzenia osiągania przez studentów zakładanych efektów kształcenia.

Współcześnie trudno wyobrazić sobie realizację procesów kształcenia bez wykorzystania możliwości mediów cyfrowych (elektronicznych ${ }^{1}$ ) takich jak biblioteki cyfrowe, e-booki, prezentacje multimedialne, nagrania audio-wideo, czy cyfrowe media interaktywne, $\mathrm{w}$ tym poczta elektroniczna, strony internetowe, fora dyskusyjne, bądź (coraz częściej) gry komputerowe. Przyjmuje się nawet, że media elektroniczne wręcz zrewolucjonizowały sposób kształcenia ${ }^{2}$, wywołując zmiany oczekiwań oraz preferencji zarówno osób realizujących procesy dydaktyczne (nauczycieli, wykładowców akademickich, szkoleniowców, trenerów, mentorów), jak i odbiorców usług edukacyjnych (uczniów, studentów, doktorantów). Dynamicznie rosnące wykorzystanie zdobyczy najnowocześniejszych technologii na gruncie edukacji tłumaczy się przede wszystkim nowymi możliwościami, jakie stworzyły i stwarzają nadal media cyfrowe, w tym głównie nowoczesne technologie teleinformacyjne. Aplikacja mediów elektronicznych $\mathrm{w}$ procesach dydaktycznych intensyfikuje oraz przyspiesza proces absorpcji i asymilacji wiedzy, a także podnosi

${ }^{1} \mathrm{~W}$ pracy przyjęto, iż media cyfrowe są tożsame z mediami elektronicznymi. Wykorzystują one cyfrowy zapis treści w postaci tekstowej, graficznej i/lub audiowizualnej. Szczególny typ mediów elektronicznych stanowią media interaktywne umożliwiające użytkownikom komunikację zwrotną.

${ }^{2}$ L. Margulis, Gry w wirtualnym środowisku nauczania, e-mentor, 2005, 1(8), s. 83. 
efektywność nauczania ${ }^{3}$. Ponadto, ich wykorzystanie wpływa pozytywnie na tworzenie oraz rozwój kluczowych, a jednocześnie często brakujących absolwentom szkół wyższych takich kompetencji, jak ${ }^{4}$ : analityczne i krytyczne myślenie, rozwiązywanie problemów, czy umiejętność współpracy i dzielenia się wiedzą. Jak dowodzą wyniki badań prowadzonych przez Bank Światowy, skutkiem cyfryzacji i digitalizacji otaczającego nas świata jest konieczność włączenia szerokiego spectrum mediów elektronicznych w realizację procesów dydaktycznych. Okazuje się, że skuteczne nauczanie wymaga wykorzystania zróżnicowanych kanałów przekazu, w tym mediów cyfrowych, a nauczane obecnie jednostki muszą być edukowane $\mathrm{w}$,"zupełnie inny sposób aniżeli byli nauczani sami nauczyciele" ${ }^{\prime 5}$. Wobec stałego upowszechniania wykorzystania mediów cyfrowych w edukacji pojawia się pytanie, czy ich aplikacja jest postrzegana jako potrzebna, zasadna przez kluczowych uczestników procesu kształcenia, to jest nauczycieli akademickich oraz studentów.

\section{Zarys metodyki badań}

Przedmiotem przeprowadzonych badań było poznanie opinii społeczności akademickiej Uniwersytetu Ekonomicznego w Katowicach na temat zasadności aplikacji mediów cyfrowych w celu realizacji procesów dydaktycznych ${ }^{6}$. Dla osiągnięcia postawionych celów badawczych w kwietniu 2015 roku przeprowadzono badania ilościowe, wykorzystując technikę ankietowania internetowego. Zaproszenie do udziału w badaniu zostało skierowane do wszystkich studentów oraz pracowników ${ }^{7}$ Uniwersytetu Ekonomicznego w Katowicach posiadających konto poczty elektronicznej na serwerze uczel-

${ }^{3}$ P. Rizzi, J. Woźniakiewicz, Perspektywy zastosowania gier symulacyjnych w edukacji-teoria i praktyka, Homo Communicativus, 2008, 3(5), s. 59-60; W. Pokojski, J. Różański, J. Wicińska, Wdrażanie e-learningu w szkole wyższej na przykładzie Wszechnicy Polskiej Szkoty Wyższej TWP, ementor, 2011, 4(41), s. 67.

${ }^{4}$ Artykuł autorki - dla dochowania wymogu "blind review" odpowiedni przypis referencyjny zostanie podany po zakończeniu procedury recenzyjnej.

5 Y. Wang, Education in a changing world: flexibility, skills, and employability, Washington 2012, s. 39.

${ }^{6}$ Prezentowane $\mathrm{w}$ artykule wyniki stanowią fragment rezultatów szerszych badań, których celem było rozpoznanie skali (częstotliwości), konieczności oraz skuteczności wykorzystywania nowych mediów na poziomie szkolnictwa wyższego. Niniejszy artykuł odnosi się jedynie do kwestii konieczności aplikacji mediów elektronicznych, natomiast wyniki dotyczące pozostałych aspektów były przedmiotem innych (np. dla dochowania wymogu "blind review" odpowiedni przypis referencyjny zostanie podany po zakończeniu procedury recenzyjnej).

7 Z uwagi na znaczne rozbieżności w możliwościach aplikacji mediów elektronicznych w różnych formach zajęć dydaktycznych (lektorat, wykład, ćwiczenia, laboratorium, seminarium), przedmiot badania ograniczono wyłącznie do zajęć posiadających status ćwiczeń. Dlatego, w treści zaproszenia do badań wyeksponowano fakt, iż badanie dotyczy jedynie tego typu 
ni. Kwestionariusz przygotowano i udostępniono potencjalnym respondentom w serwisie SurveyMonkey ${ }^{\mathrm{TM} 8}$. Za pośrednictwem ankiety respondentom zadano trzy pytania odnośnie potrzeby stosowania mediów elektronicznych: (1) przez prowadzących zajęcia dla wsparcia studentów w osiąganiu efektów kształcenia; (2) przez studentów dla osiągania przez nich efektów kształcenia; (3) w celu komunikacji na linii prowadzący zajęcia - studenci.

Pytania miały formę zamkniętą, a respondentów proszono w nich o wyrażenie opinii na temat różnego typu metod, technik, narzędzi, czy form przekazu treści w toku procesu dydaktycznego, uwzględniających wykorzystanie mediów cyfrowych. Respondenci, na podstawie swoich subiektywnych odczuć, określali natężenie potrzeby/zasadności stosowania poszczególnych mediów elektronicznych poprzez określenie ich wykorzystania jako: niepożądanego (brak rekomendacji dla wykorzystywania), niewskazanego (wykorzystanie dopuszczalne - pozytywne skutki niedostrzegalne), wskazanego (wykorzystanie zalecane - możliwe pozytywne skutki), zalecanego (wykorzystanie zalecane - bardzo prawdopodobne/pewne pozytywne skutki), lub pożądanego (wykorzystanie konieczne dla osiągnięcia celu).

Zbiór ocenianych w badaniu sposobów aplikacji mediów cyfrowych opracowano na podstawie przeglądu literatury oraz jakościowych badań rozpoznawczych przeprowadzonych w marcu 2015 roku na Uniwersytecie Ekonomicznym w Katowicach w dwóch grupach studenckich ${ }^{9}$. W badaniu wzięło udział 86 studentów oraz 66 nauczycieli akademickich, przy czym nie wszyscy uczestnicy badania udzielili odpowiedzi na każde pytanie. Wśród badanych studentów dominowały kobiety (62,5\%), osoby realizujące studia pierwszego stopnia $(75 \%)$, osoby realizujące studia $\mathrm{w}$ trybie stacjonarnym $(91,7 \%)$, studiujące na wydziale zarządzania $(68,1 \%)$. Wśród nauczycieli akademickich dominowały kobiety (54,1\%), pracownicy naukowo-dydaktyczni ze stopniem naukowym doktora zajmujący stanowisko adiunkta (76,9\%), zatrudnieni na wydziale zarządzania (35\%).

zajęć, a prośba o udział w badaniu kierowana jest wyłącznie do osób prowadzących ten typ zajęć ze studentami.

${ }^{8}$ Z uwagi na sposób formułowania pytań przygotowano dwa kwestionariusze zawierające te same, ale nieco inaczej sformułowane pytania (jest to kwestia przede wszystkim użytego słownictwa, treści zaproszenia do udziału w badaniu). Obydwa kwestionariusze były dostępne za pośrednictwem strony SurveyMonkey.com, aczkolwiek pod dwoma niezależnymi linkami. Wersja dla studentów była dostępna pod adresem: https://www.surveymonkey.com/s/ L8G6JDX, podczas gdy dostęp do wersji przygotowanej dla nauczycieli akademickich można było uzyskać pod adresem: https:// www.surveymonkey.com/s/VN8QS59.

${ }_{9}^{9}$ Dokładny opis metod, technik oraz narzędzi wykorzystanych w badaniu, służących realizacji procesów dydaktycznych opierających się w mniejszym lub większym stopniu na mediach elektronicznych, został zawarty w innym artykule autorki - dla dochowania wymogu „blind review" odpowiedni przypis referencyjny zostanie podany po zakończeniu procedury recenzyjnej. 


\section{Zasadność wykorzystania mediów elektronicznych na poziomie szkolnictwa wyższego w świetle wyników badań}

Stosowanie mediów elektronicznych w celu osiągania efektów kształcenia. Kluczowym elementem realizacji procesów nauczania na uczelni jest osiąganie przypisanych poszczególnym przedmiotom efektów kształcenia. Przyjmując, iż aplikacja mediów cyfrowych wpływa pozytywnie na sprawność procesów kształcenia ${ }^{10}$, w pierwszej części badań skupiono się na rozpoznaniu potrzeb ich stosowania w celu osiągania przez studentów zakładanych w sylabusie efektów kształcenia. W przedmiotowym obszarze zgromadzono materiał empiryczny dotyczący konieczności stosowania nowych mediów zarówno przez nauczycieli akademickich, jak i studentów.

Wykorzystanie mediów cyfrowych przez nauczycieli akademickich. Jak wskazują wyniki badania (ryc. 1), większość zarówno nauczycieli (N), jak i studentów (S) uznaje wykorzystywanie mediów elektronicznych przez prowadzących zajęcia przynajmniej za wskazane (S - średnia 3,25; N średnia 3,06). Zdaniem studentów, najbardziej konieczne jest wykorzystanie prezentacji multimedialnych ${ }^{11}$ (43\% wskazań; średnia 3,96), natomiast wykorzystanie tradycyjnej prezentacji okazuje się najbardziej potrzebną formą dla nauczycieli (44\% wskazań, średnia 4). Rozbieżność opinii wśród badanych grup może wskazywać, że dla studentów wykorzystywanie zróżnicowanych kanałów komunikacji, połączenie różnych nowoczesnych rozwiązań cyfrowych oraz orientacja na interakcje - czyli kwestie odróżniające prezentację multimedialną od prezentacji tradycyjnej - mają większe znaczenie z punktu widzenia osiągania efektów kształcenia. W takim ujęciu studenci wydają się wyrażać potrzebę nie tylko stosowania mediów elektronicznych, ale również mediów interaktywnych.

10 E. Mukama, S.B. Andersson, Coping with change in ICT-based learning environments: Newly qualified Rwandan teachers' reflections, Journal of Computer Assisted Learning, 2008, 24(2), s. 164; P. Rizzi, J. Woźniakiewicz, Perspektywy zastosowania gier symulacyjnych, s. 59-60.

${ }_{11} \mathrm{~W}$ badaniu rozróżniono pojęcie prezentacji oraz prezentacji multimedialnej. Prezentacja multimedialna wykorzystuje zbiór różnych mediów tak, aby w zróżnicowany sposób przekazać treść komunikatu. Co więcej, w literaturze podkreśla się, że o ile prezentacja tradycyjna (nawet wykorzystująca oprogramowanie komputerowe oraz różne formy przekazu) nastawiona jest na komunikację jednokierunkową, to prezentacja multimedialna zakłada komunikację dwukierunkową oraz konieczność interakcji z odbiorcami. Zob. np. W.M. Barański, T. Walkowiak, Multimedialna technologia nauczania w Internecie, [w:] Nowe media w edukacji. Osiagnięcia pracowników Politechniki Wrocławskiej w zakresie nauczania z wykorzystaniem nowych mediów, Wrocław 2005, s. 13-20; J. Jędryczkowski, Prezentacje multimedialne w procesie uczenia się studentów, Toruń 2005. 
Studenci (średnia 3,25; $\mathrm{n}=80$ )

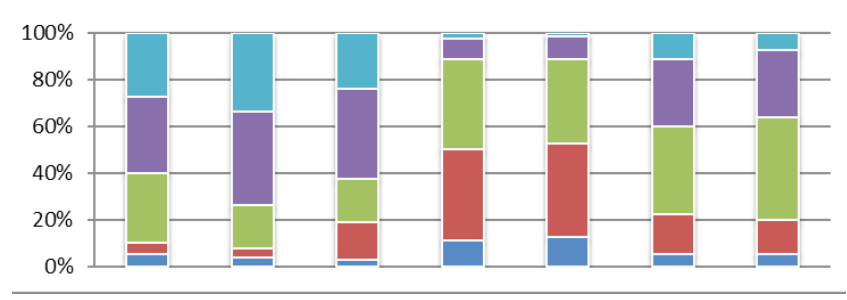

Nauczyciele akademiccy (średnia 3,06; $\mathrm{n}=50$ )

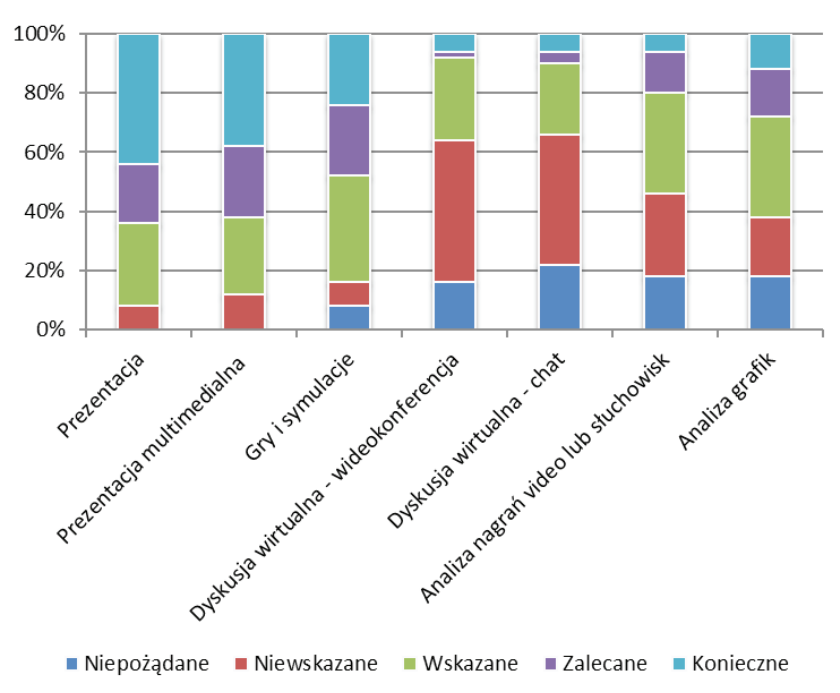

Ryc. 1. Opinie dotyczące stosowania przez nauczycieli akademickich mediów elektronicznych w procesie kształcenia

(źródło: opracowanie własne)

W obydwu grupach najczęściej jako niepożądaną wskazywano dyskusję wirtualną z wykorzystaniem chatu (S - średnia 2,48; 12,5\% wskazań; N - średnia 2,28, 22\% wskazań). Uzyskane wyniki potwierdzają rezultaty wcześniejszych badań ${ }^{12}$, wskazujących, iż nowe media stosowane $\mathrm{w}$ dydaktyce, $\mathrm{w}$ tym zwłaszcza media elektroniczne pozwalające realizować procesy dydaktyczne na odległość, powinny raczej uzupełniać i wzbogacać, a nie stanowić substytut tradycyjnych metod kształcenia. Co ciekawe, największa rozbieżność opinii studentów i nauczycieli widoczna jest w odniesieniu do analizy nagrań

12 M. Kierzek, M. Tyburski, Badanie potrzeb i oczekiwań studentów i pracowników w kontekście rozwoju e-edukacji w Akademii Ekonomicznej w Poznaniu, e-mentor, 2005, 1(8), s. 42. 
wideo lub słuchowisk (np. pozyskanych z TED, Vimeo, YouTube bądź produkcji własnej). W tym przypadku niemal połowa nauczycieli wskazywała odpowiedzi niepożądane/niewskazane, podczas gdy większość studentów oceniła ich stosowanie jako wskazane, a nawet zalecane.

Wykorzystanie mediów cyfrowych przez studentów. Obydwie grupy badanych oceniają wykorzystywanie mediów elektronicznych przez studentów przynajmniej jako wskazane (S - średnia 3,40; N - średnia 3,36; ryc. 2). Jako najbardziej pożądane studenci wskazują praktyczne prezentacje multimedialne, to jest łączące w sobie różne formy przekazu, tworzone na podstawie analizy konkretnego przykładu z praktyki gospodarczej (30\% wskazań; średnia 3,89). Podobnie jak poprzednio, w przypadku nauczycieli jako bardziej pożądana

Studenci (średnia 3,40; $\mathrm{n}=73$ )

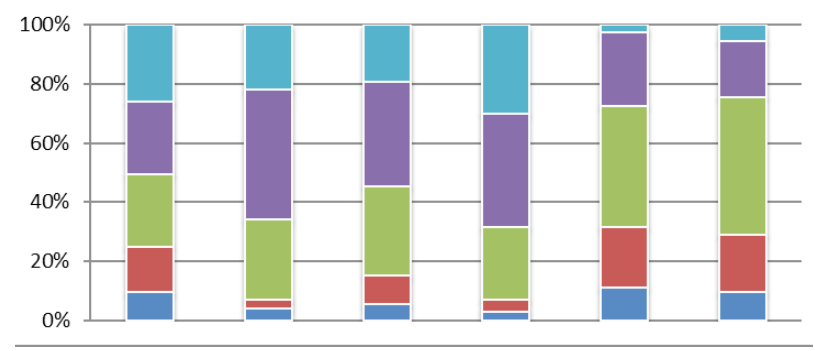

Nauczyciele akademiccy (średnia 3,36; $\mathrm{n}=42$ )

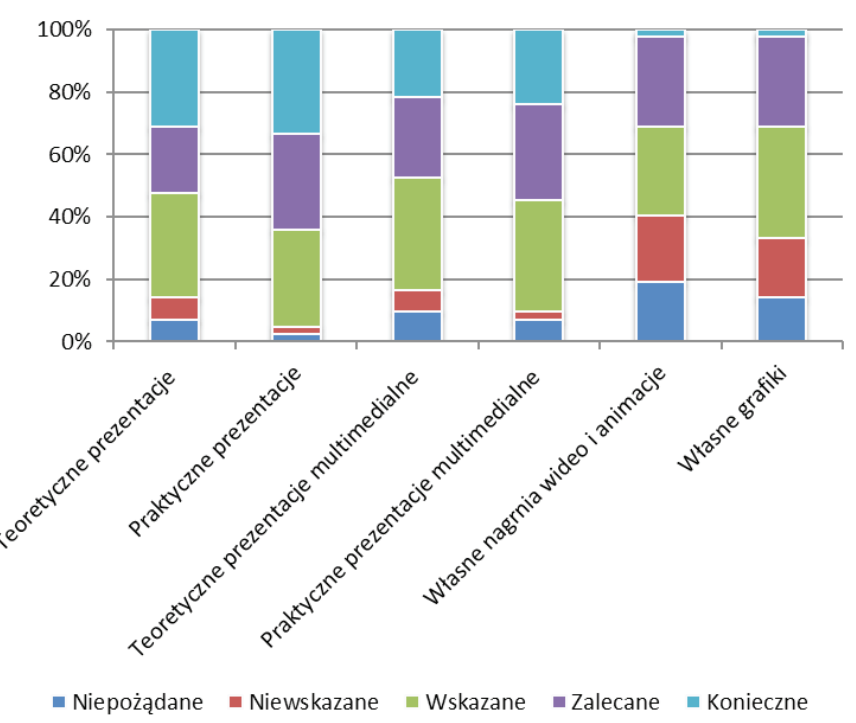

Ryc. 2. Opinie dotyczące stosowania przez studentów mediów elektronicznych $\mathrm{w}$ procesie kształcenia

(źródło: opracowanie własne) 
forma wskazywana jest praktyczna prezentacja tradycyjna, opierająca się na analizie studium przypadku (33\% wskazań; średnia 3,9). Warto zauważyć, iż obydwie grupy postrzegają przygotowywanie przez studentów prezentacji opierających się na analizie przykładów praktycznych jako najbardziej znaczących dla osiągania efektów kształcenia, przy czym studenci wydają się nieco bardziej skłonni do aplikacji bardziej złożonych mediów cyfrowych integrujących różne środki przekazu (preferują prezentacje multimedialne).

Najmniej pożądaną formą stosowania mediów elektronicznych przez studentów okazuje się przygotowywanie własnych nagrań wideo lub animacji w środowisku cyfrowym (S - średnia 2,88, 11\% wskazań; N - średnia 2,74, 19\% wskazań) - potwierdza to wyniki badań wskazujących, iż pracochłonność stanowi barierę stosowania tego typu nowoczesnych rozwiązań w dydaktyce ${ }^{13}$. Warto zwrócić uwagę, że w opinii nauczycieli dobrą formą dydaktyczną jest prezentacja teoretyczna przygotowywana przez studentów (86\% badanych określa ją jako przynajmniej wskazaną, w tym 31\% jako pożądaną), podczas gdy co czwarty student postrzega tę formę jako nieistotną dla osiągania efektów kształcenia (forma niepożądana - 10\%, forma niewskazana - 15\%).

Stosowanie mediów elektronicznych $\mathbf{w}$ celu usprawnienia przebiegu procesu dydaktycznego. Aplikacja mediów cyfrowych na rzecz osiągania efektów kształcenia to nie jedyny kierunek ich wykorzystania w realizacji procesów dydaktycznych. Kolejnym obszarem ich zastosowania jest komunikacja odbywająca się pomiędzy prowadzącymi zajęcia a studentami. W tym zakresie media cyfrowe mogą stanowić dodatkowy kanał komunikacyjny usprawniający organizację, a także przebieg procesu dydaktycznego - na przykład poczta elektroniczna wykorzystywana w celu przekazywania informacji organizacyjnych, dystrybucji materiałów dydaktycznych, przesyłania prac zaliczeniowych, czy raportowania ocen.

Biorąc pod uwagę możliwość wykorzystywania szerokiego instrumentarium nowoczesnych technologii na potrzeby komunikacji uczestników procesu dydaktycznego, poproszono badanych o ocenę zasadności wykorzystywania różnych form komunikacji elektronicznej - wyniki przedstawiono na rycinie 3. W świetle uzyskanych rezultatów można stwierdzić, iż najbardziej istotnym kanałem komunikacji, opartym na nowych technologiach jest poczta elektroniczna. Obydwie grupy respondentów uznały tę formę komunikacji za pożądaną (77\% studentów oraz $68 \%$ nauczycieli). Podobna zgodność opinii występuje w odniesieniu do najmniej pożądanego kanału komunikacji w postaci blogów lub wideoblogów prowadzonych przez nauczycieli akademickich (45\% nauczycieli oraz $22 \%$ studentów).

${ }^{13}$ K. Wojtaszczyk, M. Striker, Obawy przed uczeniem się na odległość - opinie łódzkich studentów, e-mentor, 2011, 4(41), s. 46. 
Studenci (średnia 3,25; $\mathrm{n}=78$ )

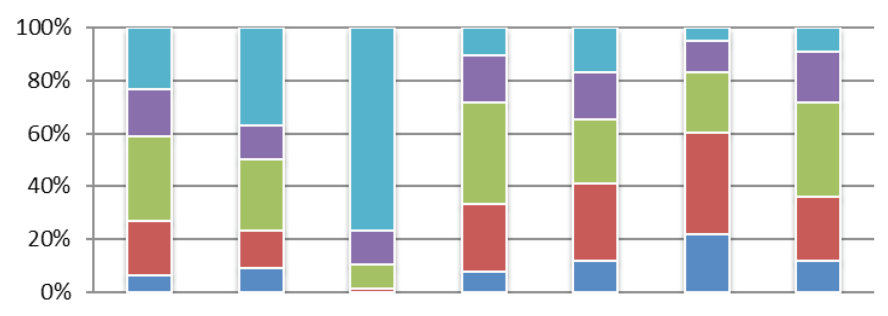

Nauczyciele akademiccy (średnia 2,95; n = 47)

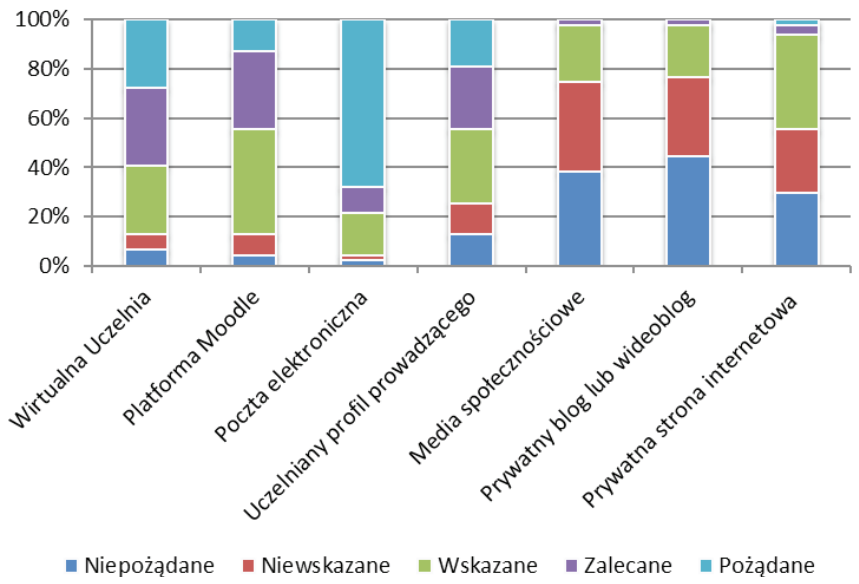

Ryc. 3. Opinie odnośnie do stosowania mediów elektronicznych w komunikacji dotyczącej procesu kształcenia

(źródło: opracowanie własne)

Wyniki badań wskazują, że zarówno nauczyciele, jak i studenci jako bardziej pożądane postrzegają kanały komunikacji bezpośredniej, pozwalające na formułowanie przekazu dedykowanego ściśle określonemu studentowi lub przynajmniej grupie studentów (tj. poczta elektroniczna, platforma Moodle, Wirtualna Uczelnia). Warto zauważyć, iż zasadność wykorzystywania wszystkich rozpatrywanych kanałów komunikacji została wyżej oceniona przez studentów. Uzyskane wyniki mogą sugerować, iż nauczyciele są nieco bardziej przywiązani do tradycyjnej, bezpośredniej komunikacji ze studentami, odbywającej się w trakcie ćwiczeń bądź konsultacji. Z drugiej strony, bardziej zachowawcze opinie nauczycieli akademickich odnośnie do zasadności komunikacji cyfrowej mogą wynikać po prostu z faktu, iż młodsze pokolenia są bardziej skłonne do wykorzystywania zdobyczy nowych technologii w ogóle, w tym także w obszarze komunikacji w dydaktyce. 


\section{Podsumowanie}

Zaprezentowane $\mathrm{w}$ artykule rezultaty badań przeprowadzonych na Uniwersytecie Ekonomicznym w Katowicach potwierdzają wyniki badań prowadzonych $\mathrm{w}$ innych ośrodkach naukowych ${ }^{14}$ wskazujących, że nowoczesne technologie stanowią pożądane narzędzie realizacji oraz wzmacniania efektywności procesów kształcenia, a zatem można stwierdzić, że wykorzystanie mediów cyfrowych $\mathrm{w}$ realizacji procesów dydaktycznych na poziomie szkolnictwa wyższego jest zalecane (tab. 1).

Tabela 1

Wykorzystywanie mediów cyfrowych na Uniwersytecie Ekonomicznym w Katowicach (ujęcie procentowe)

\begin{tabular}{|l|c|c|}
\hline & \multicolumn{1}{|c|}{$\begin{array}{c}\text { Niepożądane/ } \\
\text { Niewskazane }\end{array}$} & $\begin{array}{c}\text { Wskazane/Zalecane/ } \\
\text { Pożądane }\end{array}$ \\
\hline \multicolumn{1}{|c|}{ Wykorzystywanie mediów cyfrowych przez nauczycieli akademickich } \\
\hline Studenci & 25,9 & 74,1 \\
\hline Nauczyciele akademiccy & 35,7 & 64,3 \\
\hline $\begin{array}{l}\text { Studenci } \\
\text { i nauczyciele akademiccy }\end{array}$ & 29,7 & 70,3 \\
\hline \multicolumn{2}{|c|}{ Wykorzystywanie mediów cyfrowych przez studentów } \\
\hline Studenci & 18,9 & 81,1 \\
\hline Nauczyciele akademiccy & 19,8 & 80,2 \\
\hline $\begin{array}{l}\text { Studenci } \\
\text { i nauczyciele akademiccy }\end{array}$ & 19,3 & 80,7 \\
\hline \multicolumn{2}{|c|}{ Wykorzystywanie mediów cyfrowych w komunikacji } \\
\hline Studenci & 31,7 & 68,3 \\
\hline Nauczyciele akademiccy & 37,4 & 62,6 \\
\hline $\begin{array}{l}\text { Studenci } \\
\text { i nauczyciele akademiccy }\end{array}$ & 33,8 & 66,2 \\
\hline \multicolumn{2}{|c|}{ Wykorzystywanie mediów cyfrowych na UE Katowice } \\
\hline $\begin{array}{l}\text { Studenci } \\
\text { i nauczyciele akademiccy }\end{array}$ & 28,2 & 71,8 \\
\hline
\end{tabular}

Źródło: opracowanie własne.

${ }^{14}$ Badania prowadzone w Uczelniach Ekonomicznych: M. Dąbrowski, Formy wykorzystywania technologii informacyjno-komunikacyjnych w edukacji w opinii nauczycieli $i$ studentów SGH, e-mentor, 2005, 1(8), s. 43-44; M. Kierzek, M. Tyburski, Badanie potrzeb i oczekiwań studentów, s. 38-42; J. Krasodomska, E-learning w nauczaniu rachunkowości - wyniki badań ankietowych, e-mentor, $2012,1(43)$, s. $48-52$. 
We wszystkich badanych aspektach nauczyciele oceniali zasadność aplikacji nowych mediów w dydaktyce na niższym poziomie aniżeli studenci. Większa liczba odpowiedzi o etykietach "niepożądane” i „niewskazane” wśród nauczycieli może wynikać z braku wiedzy o ich istnieniu, braku umiejętności ich wykorzystania, stosunkowo dużej pracochłonności zastosowania, barier infrastrukturalnych uczelni związanych z brakiem dostępu do sprzętu audio-wideo, czy projektorów multimedialnych. Niektóre potencjalne bariery wykorzystywania nowoczesnych technologii identyfikowano już we wcześniejszych badaniach, prowadzonych między innymi w Szkole Głównej Handlowej w Warszawie ${ }^{15}$, czy na Uniwersytecie Łódzkim ${ }^{16}$. Niniejsze badania, a dokładniej zidentyfikowane rozbieżności widoczne w opiniach prowadzących zajęcia oraz studentów mogą wskazywać na istnienie pewnej luki kompetencyjnej nauczycieli akademickich, którzy reprezentują starsze, mniej skomputeryzowane, czy interaktywne pokolenie. W takim ujęciu warto rozważyć możliwość wdrożenia odpowiednich szkoleń, warsztatów dotyczących stosowania mediów cyfrowych w dydaktyce, zwłaszcza mediów interaktywnych oraz mobilnych.

W wypadku badanej uczelni za najbardziej pożądaną formę wykorzystania mediów cyfrowych $w$ trakcie realizacji ćwiczeń można uznać prezentację multimedialną. Wysoki stopień zasadności stosowania tego typu prezentacji może wynikać z faktu, iż stanowi ona dobry przykład narzędzia dydaktycznego, które w bardzo zróżnicowany - dostosowany do różnych preferencji nadawców oraz odbiorców - sposób może wykorzystywać nowe media, takie jak: nowoczesne oprogramowanie komputerowe służące przygotowaniu szkieletu prezentacji (np. MS PowerPoint, Keynote, Flowboard, 9slides, Prezi, Haiku Deck), nagrania audio-wideo pozyskane z Internetu (np. filmiki z YouTube'a, przemówienia i prezentacje z platform typu TED) lub przygotowane samodzielnie elementy graficzne $w$ postaci ruchomych animacji, chmur słów (np. opracowanych w Wordle.net, TagCrowd.com, czy Tagxedo. com), infografik (np. stworzonych z wykorzystaniem programów: Piktochart, Easel.ly, Visual.ly), map myśli (opracowanych za pomocą np. MindMeister, SpiderScribe, Freemind). W zależności od zaawansowania technologicznego osoby przygotowującej prezentację multimedialną, a także dostępnych środków technicznych, finansowych oraz czasowych, prezentacja multimedialna jest narzędziem bardzo elastycznym i funkcjonalnym. Zdaniem autorki, wysoki poziom ocen konieczności stosowania tego typu prezentacji można powiązać także $\mathrm{z}$ faktem, iż wykorzystywane $\mathrm{w}$ nich równolegle różne formy przekazu treści pozwalają odbiorcom gromadzić wiedzę w zróżnicowa-

${ }^{15}$ M. Dąbrowski, Formy wykorzystywania technologii informacyjno-komunikacyjnych, s. 43-44.

${ }^{16}$ M. Striker, K. Wojtaszczyk, Bariery wdrażania e-learningu na przykładzie uczelni wyższej (cz. II), e-mentor, 2009, 5(32), s. 46-50. 
ny sposób. Integracja komunikacji wizualnej i dźwiękowej oraz możliwość wprowadzenia komponentów dynamicznych pozwala skuteczniej przekazywać treści dydaktyczne wszystkim odbiorcom, bez względu na dominujący u nich styl uczenia ${ }^{17}$.

\section{BIBLIOGRAFIA}

Artykuł własny - dla dochowania wymogu „blind review" - odpowiedni przypis referencyjny zostanie podany po zakończeniu procedury recenzyjnej.

Barański W.M., Walkowiak T. Multimedialna technologia nauczania w Internecie, [w:] Nowe media w edukacji. Osiagnięcia pracowników Politechniki Wroctawskiej w zakresie nauczania z wykorzystaniem nowych mediów, Oficyna Wydawnicza Politechniki Wrocławskiej, Wrocław 2005.

Dąbrowski M., Formy wykorzystywania technologii informacyjno-komunikacyjnych w edukacji w opinii nauczycieli $i$ studentów SGH, e-mentor, 2005, 1(8).

Jędryczkowski J., Prezentacje multimedialne w procesie uczenia się studentów, Wydawnictwo Adam Marszałek, Torun 2005.

Kierzek M., Tyburski M., Badanie potrzeb i oczekiwań studentów i pracowników w kontekście rozwoju e-edukacji w Akademii Ekonomicznej w Poznaniu, e-mentor, 2005, 1(8).

Krasodomska J., E-learning w nauczaniu rachunkowości-wyniki badań ankietowych, e-mentor, $2012,1(43)$.

Margulis L., Gry w wirtualnym środowisku nauczania, e-mentor, 2005, 1(8).

Mukama E., Andersson S.B., Coping with change in ICT-based learning environments: Newly qualified Rwandan teachers' reflections, Journal of Computer Assisted Learning, 2008, 24(2).

Pokojski W., Różański J., Wicińska J., Wdrażanie e-learningu w szkole wyższej na przykładzie Wszechnicy Polskiej-Szkoły Wyższej TWP, e-mentor, 2011, 4(41).

Rizzi P., Woźniakiewicz J., Perspektywy zastosowania gier symulacyjnych w edukacji-teoria i praktyka, Homo Communicativus, 2008, 3(5).

Rybak A., Przykłady systemów zdalnej edukacji, realizujacych dobór strategii nauczania do stylu uczenia sie, [w:] E-learining w szkolnictwie wyższym - potencjat $i$ wykorzystanie, red. J.D. Antoszkiewicz, J. Goliński, Fundacja Promocji i Akredytacji Kierunków Ekonomicznych, Warszawa 2010.

Striker M., Wojtaszczyk K., Bariery wdrażania e-learningu na przykładzie uczelni wyższej (cz. II), e-mentor, 2009, 5(32).

Wang Y., Education in a changing world: flexibility, skills, and employability, World Bank, Washington 2012.

Wojtaszczyk K., Striker M., Obawy przed uczeniem się na odległość - opinie łódzkich studentów, e-mentor, 2011, 4(41).

17 Przyjmując trójwymiarową klasyfikację stylów uczenia się według VAK Learning Styles, obejmującą: uczenie się poprzez patrzenie i czytanie (visual perception), uczenie się przez słuchanie i mówienie (auditory learning) oraz uczenie się przez dotykanie i działanie (kinesthetic learning). Cyt. za: A. Rybak, Przykłady systemów zdalnej edukacji, realizujacych dobór strategii nauczania do stylu uczenia się, [w:] E-learning w szkolnictwie wyższym - potencjat $i$ wykorzystanie, red. J.D. Antoszkiewicz, J. Goliński, Warszawa 2010, s. 128. 